\title{
Peeling Potatoes as Health Promotion? Self-Perceived Benefits of Volunteering among Older Adult Volunteers in a Norwegian Volunteer Centre
}

\author{
Anita Berg, Oddbjørn Johansen \\ Faculty of Nursing and Health Sciences, Nord University, Namsos, Norway \\ Email: anita.berg@nord.no
}

How to cite this paper: Berg, A. and Johansen, O. (2017) Peeling Potatoes as Health Promotion? Self-Perceived Benefits of Volunteering among Older Adult Volunteers in a Norwegian Volunteer Centre. Open Journal of Social Sciences, 5, 171-189. https://doi.org/10.4236/jss.2017.54016

Received: March 9, 2017

Accepted: April 25, 2017

Published: April 28, 2017

Copyright ( 92017 by authors and Scientific Research Publishing Inc. This work is licensed under the Creative Commons Attribution International License (CC BY 4.0).

http://creativecommons.org/licenses/by/4.0/ (c) (i) Open Access

\begin{abstract}
In recent years, voluntary work undertaken by older people has been viewed as a possible way to link aging populations with individual and societal needs related to healthy aging. Based on focus group interviews, the study aims to clarify how volunteering is maintained in older populations and examines how older adults (aged 65+ years) in a Norwegian volunteer centre perceived the benefits of volunteering. The results of the study highlight the importance of the volunteer centre as a place in which to participate and be social, for a sense of belonging to a fellowship of co-volunteers, and as an arena for personal growth and adaption to old age. These aspects were described by the volunteers as health promoting. Additionally, the context of the voluntary work, as the volunteer activities and the way they were organized, was significant for their experiences. From these findings, it is a need for in-depth studies of the dynamics of everyday volunteer work in order to gain a better understanding of the relationship between self-rated health benefits and the organizational contexts in which older adults retain to work voluntarily.
\end{abstract}

\section{Keywords}

Health Promotion, Older Adults, Self-Perceived Benefits, Volunteering, Well-Being

\section{Introduction}

Worldwide, in almost every country including Norway, the proportion of the population in the age group 60+ years is growing faster than any other age group, and the number of people over 60 years is estimated to double by 2050 
[1]. This demographic change has raised awareness of active and healthy ageing, and the need for prolonged good health in later life in order to increase the ageing populations' quality of life and save on costs to society. Volunteering is seen as beneficial to older adults and the communities in which they live [2] and is described as a pathway to productive and social engagement among older adults [3].

Volunteering is broadly defined by the United Nations Volunteers (UNV) as an action that is undertaken freely and without coercion, for reasons other than financial gain, and is undertaken to benefit the community as well as the volunteer [4]. In 1991, the Norwegian Ministry of Labour and Social Affairs initiated the establishment of volunteer centres in the municipalities. The purpose of the centres was to mobilize the unemployed, the disabled, and pensioners, all groups that are otherwise poorly represented in mainstream volunteer organizations [5]. The idea was that new groups of volunteers could contribute to activities in the interests of the local communities and new meeting places would be created for the inhabitants that would offer them the opportunity to use their productive capacity. Today, there are 418 volunteer centres in Norway [6], organized in a variety of ways, and operating in the gap between the public services and the private organizations running open, not-for-profit, low-threshold services. This study examines how older adults (aged 65+) in one Norwegian volunteer centre perceived the benefits of volunteering and why they continued to volunteer.

\section{Literature Review}

Volunteering has a strong tradition in Norway. In a study conducted in 2014, based on the UNV definition of volunteering, 61 per cent of the adult population in the age group 16 - 79 years reported that they had participated in some sort of voluntary work during the past 12 months [7]. From the age of 50 years onwards, the hours of volunteering decrease rapidly in Norway and the same mechanisms of exclusion as in work life are seen in volunteering and are related to socio-economic variables, age, and health [8]. Knowledge of maintenance factors, such as older adults' self-perceived benefits, is important in order to achieve the political goals of active and healthy ageing through volunteering.

There are numerous reasons why older adults become and continue to be volunteers. The explanations relate to the characteristics of the volunteers, to environmental circumstances, and to the organizational aspects of the voluntary work [9]. On a personal level, motives such as wanting to be helpful to others [10], as well as "paying back" society and having a sense of obligation to future generations [11] are common explanations for older adults' engagement in voluntary work.

Studies have reported a relationship between volunteering and positive outcomes for older adults. Volunteering among older adults is associated with a number of health benefits, such as reduced symptoms of depression [12], better self-reported health [13] [14], and lower rates of mortality [15] [16]. Volunteering in later life can give volunteers psychosocial benefits in the form of self- 
worth and socialization [17], as well as higher levels of self-rated life satisfaction [18]. Older adult volunteers have reported an increase in their quality of life due to feeling appreciated, having a sense of purpose, and being able to "give something back" [19].

For older adults, voluntary work can be an arena for significant social participation [9] [20]. Participation in activities with other volunteers who share the same interests and priorities, and positive feedback from the beneficiaries of volunteers' efforts have been found to give older volunteers a valued sense of collective identity and sense of belonging [21]. Additionally, those who volunteer in later life have been found to have an increased sense of well-being compared to those who do not participate in voluntary work [22] [23]. A study conducted by Van Willingen [24] found that the oldest volunteers (60+) appeared to reap greater benefits for each hour of volunteering than the younger volunteers in terms of positive changes in their self-perceived health.

Literature describing the relationship between older adults' motives to volunteer and their motives to continue volunteering suggests that a change occurs from "altruistic" motives based on moral values and social obligations towards valuing the more "egoistic" motives for being a volunteer and this explains why they continue to volunteer [11]. Furthermore, with increasing age, social motives and making friends become more prominent reasons for volunteering [25]. In addition to the opportunities to develop new friendships, the possibilities for acquiring new knowledge and accessing a community of learning have been reported as prominent reasons for older adults to do voluntary work [11] [26]. This may indicate that volunteering in later life has several functions in the lives of older adults' volunteers and moderates the effects of the loss of their role identity [27]. Moreover, such role enhancement is a source of support in their transition into old age [13].

Volunteering can be viewed as two sides of a coin, one benefiting society and the other benefiting the volunteer, who gains a sense of "doing well by doing good" [28]. Our study explores the latter perspective though older adult volunteers' descriptions of self-perceived benefits in the context of a Norwegian volunteer centre. Despite an increased interest in volunteering by older adults in recent decades, research on the experiences of volunteering has remained generally neglected, particularly regarding the influence that the social context of voluntary work may have on volunteers' feelings of satisfaction and commitment [29]. This study contributes to our understanding of the social context in older adult volunteering, and how it affects well-being and retention by examining self-perceived benefits and how these benefits are created in social interactions at a volunteer center.

\section{Method}

Qualitative research aims to access the experiences of social phenomena in the terms of the meanings people bring to them [30]. This study is based on focus group interviews. The purpose of focus group interviews is to generate qualita- 
tive data from the participants' experiences of a "particular concrete situation' [31], which in our case were older adults" experiences of self-perceived benefits and their motives to continue as volunteers at a Norwegian volunteer centre. One of the benefits of focus groups lies in the examination of a topic that the participants may not necessarily have reflected upon or vocalized earlier by taking the advantage of the group dynamics that allow for deliberation among the participants [32]. Focus groups are particularly useful for allowing participants to express their own priorities in their own terms and in their own vocabulary [33]. In our study, the volunteers' stories about older adult voluntary work at their volunteer centre were framed in the community, the history, organization, and activities of the volunteer centres, and ageing in rural Norway.

\subsection{Sampling and Participants}

The case volunteer centre was located in a village with 3700 inhabitants in a small rural municipality. The centre had a high number of older adult volunteers and no dropouts, and was therefore considered appropriate as a case study in order to find answers to our research question. Approximately 65 older adult volunteers managed the centre, providing services such as dinners for the villagers, school lunches, and a knitting café, and hosting darts competition and running a second-hand shop. All services were provided once per week. The primary activity was preparing dinners and most volunteers were organized in permanent "cooking teams", with 8 - 13 members in each team. Each team prepared and served dinner at the volunteer centre for on average 250 guests from the local community, every fifth week. The volunteers themselves often used the centre's services when they had the opportunity. The manager was the only paid full-time member of staff.

Sampling in qualitative research is guided by who best fits the purpose of the study [34]. Further, the composition of a focus group should balance variation and homogeneity [35]. We selected a sample of 18 older adult volunteers in the age group 66 - 83 years. Based on our request to include volunteers of different genders, ages, lengths of time spent at the centre, the manager of the volunteer centre sent written requests by post to members of the permanent teams.

The manager of the volunteer centre organized nine men and nine women in three groups: a men's group, a women's group, and a mixed group. The average age of the participants was 76 years (median 77 years). The participants had been volunteers for between one and seven years, and had an average of four and a half years of experience. Some of them had been volunteers since the establishment of the centre in 2008, while others had not been there as long as a year. Eight of them were living alone. We tried to improve the diversity in the sample since we anticipated that this would help to clarify the information we acquired.

The focus group discussions were held in June 2015 and each interview lasted on average 78 minutes. We audiotaped and transcribed the three discussions verbatim. The identity of all participants was kept anonymous in the study materials and anonymity has also been preserved in this article. The group dynam- 
ics was a resource in the interviews and volunteers themselves mainly led the conversations by expanding upon, nuancing, and exemplifying each other's statements. Their engagement and desire to explore the research topic was both an advantage and disadvantage of the method. Focus group discussions were an advantage in terms of generating opportunities for a broader and more nuanced perspective on older adult volunteering than might have been possible in individual interviews. The approach can be important for highlighting any themes that attract consensus [32]. The disadvantage of the approach relates to participants' co-creation and confirmation of a "master narrative", which may make it more difficult for individuals to disagree. In our case, the participants' eagerness to help us to understand how older adult volunteering works made them speak about the benefits for the other volunteers at the centre or for older adult volunteers in general, thereby omitting their own perspective, and most often such claims remained unchallenged by other members of the groups.

\subsection{Data Analysis}

According to Morgan [36], the goals of research should guide the analysis of the data acquired from focus groups discussions. In focus group studies with explorative purposes, it is most appropriate to conduct a thematic, data-based analysis aiming to summarize the participants' stories in a way that leads to new insights into the phenomenon under study [35]. Thematic "bottom-up" analytical approaches are data-driven and not tied to any existing theoretical framework [37]. The purpose of our study was to explore older volunteers' self-perceived benefits of volunteering in broad terms, and the interactions in the focus groups were seen a way of generating relevant data, rather viewing them as the data [36]. Inductive content analysis was used in the data analysis in order to describe the studied phenomenon as a concept [38]. First, our analysis focused on what people actually said, and second, we followed the interactive context of their statements in our transcripts of the dialogues. The analysis started with open coding, wherein we asked what were they talking about and what topics were raised in the discussions. An example of the open coding from our analysis is given in Table 1.

Based on the initial coding, the descriptive categories were condensed and abstracted into three higher order themes, which included several subthemes. The

Table 1. An example of open coding from the analysis.

\begin{tabular}{|c|c|c|c|c|}
\hline Meaning unit & $\begin{array}{l}\text { Condensed } \\
\text { meaning unit }\end{array}$ & Code & Subtheme & Theme \\
\hline $\begin{array}{l}\text { "When being retired I } \\
\text { think it is good to } \\
\text { know I have } \\
\text { something to go to, } \\
\text { and at least I believe } \\
\text { that I can be useful to } \\
\text { someone else" }\end{array}$ & $\begin{array}{l}\text { Having } \\
\text { something to do } \\
\text { that also can be } \\
\text { valued by others }\end{array}$ & $\begin{array}{l}\text { Being active and } \\
\text { feeling useful as a } \\
\text { pensioner }\end{array}$ & $\begin{array}{c}\text { Volunteering as a } \\
\text { meaningful } \\
\text { content in } \\
\text { everyday life }\end{array}$ & $\begin{array}{c}\text { Volunteering as } \\
\text { participating in } \\
\text { society }\end{array}$ \\
\hline
\end{tabular}


themes and subthemes are presented in Table 2 in the "Results" section. In this process, we tested the results against the audiotape recordings and transcripts. We examine the relationships between themes and subthemes in the "Discussion" section.

\subsection{Trustworthiness}

In qualitative research, techniques searching for disconfirming evidence should be applied when possible [39]. In studies of self-perceived benefits and retention in volunteering the results are most likely to be positive, since volunteers act freely. To ensure the trustworthiness of the results and conclusions drawn from the analysis, we conducted a member check. Securing feedback from participants or others similar to them is one of several methods used to check the credibility of the categories, themes, or accounts in qualitative research [40]. To conduct the member check, we attended the annual meeting of the volunteers held at the volunteer centre and gave a short presentation of our findings and conclusions. The meeting was attended by participants from the focus groups and other older adult volunteers, totalling approximately 45 persons. After follow-up group discussions during the coffee break, the older volunteers in the meeting confirmed the categories and the conclusions in our study, but they missed one element in our presentation of the findings related to the topic social support, namely the value of "being seen". This was experienced as a feeling of care, of their importance being acknowledged by their co-volunteers and manager in their presence, and finally their knowledge that they would be missed if they did not come to work at the centre. In response to this feedback, we highlight this experience below, in the subtheme "social support of co-volunteers" in the "Results" section.

\section{Results}

The "social" element appeared as both a reason to engage in and to benefit from engaging in voluntary work, and was as "the chorus" in the participants' descriptions of being volunteers. The volunteer centre was described as a beehive of activity and the social element as having a pivotal role in voluntary work in old age. With regard to the volunteers' understanding of their self-rated benefits of voluntary work, there were no distinctions in practice between the groups or between the study participants with regard to age, gender, or the amount of time they spent volunteering. Thus, the analysis of the discussions revealed greater self-perceived benefits for the eight volunteers who lived alone than for the other volunteers related to their statements.

When we analysed the transcripts with regard to the context of the social element in older adult voluntary work, three main themes appeared: the opportunity to participate in society through volunteering, a sense of belonging to a group of co-volunteers and the accompanying sense of fellowship, and volunteering as an opportunity for growth and adaptation to old age. These main themes and their underlying subthemes are presented in the following. 
Table 2. Themes and subthemes.

\begin{tabular}{cll}
\hline \multicolumn{1}{c}{ Main themes } & \multicolumn{1}{c}{ Subthemes } \\
\hline Volunteering as participating in society & - & Volunteering as meaningfulcontent in \\
everydaylife \\
& - Retirement and change in roles \\
& - Access to a social arena \\
Belonging to a groupof co-volunteers & - Expandingthesocialnetwork \\
& - Social support by co-volunteers \\
Growth and adaption to old age & - Feeling productive and empowered by \\
& & newchallenges and collaboration \\
& - Forgettingaboutthechallengesofageing \\
& - "door-opener" to activeageing \\
\hline
\end{tabular}

\subsection{Volunteering as Participating in Society}

When the participants explained why they were volunteers, they highlighted their phase of life and going into retirement. Volunteering gave them meaningful content in everyday life, represented an opportunity to stay connected to other members of their community in times of role transition, and gave them access to a social arena.

Volunteering thus represented meaningful content in everyday life. One of the women explained: 'When being retired, I think it is good to know I have something to go to, and at least I believe that I can be useful to someone else.' As pointed out here, to be active in daily life and to be of use for others was essential for the participants' engagement as volunteers. In this context, "something to go to" related to the establishment of the local volunteer centre. As in other parts of rural Norway, the municipality had closed down the local retirement home in the village and moved the residents to the nursing home in the community centre. The villagers wanted the empty home to be used for new activities, and several volunteer organizations took over the building without having to pay for the usage. With a complete and functional institutional kitchen, the board of the volunteer centre wanted to start serving dinners based on traditional home cooking, once per week. Older adults appeared attractive as volunteers due to their experience of traditional cooking and the fact that the meals had to be prepared in the daytime.

As older adults, it was possible to volunteer at a time in life when they had fewer social commitments than before. Retirement and changes in roles were profoundly important to them, as one of the men stated:

I am glad this house came to use. We were cursed when they let down the old home, but actually it was good. Now they are forgiven [...] This [volunteer centre] is an offer to volunteer for many who otherwise wouldn't have access to voluntary work. We are fifty to sixty seniors here on a voluntary basis. If we didn't have this, what would we have done? There isn't so much to engage in. We don't have kids to drive to training [sessions] any more. We are done with that period of life. 
Retirement releases a lot of spare time and many of the volunteers no longer felt needed by their families and local organizations. They had entered a period in life in which many of them felt the need for a new role in society. By working at the centre, with popular services and contact with many guests, volunteering gave them a new role, which they valued because it enabled them to feel they were appreciated by others.

Volunteering gave access to a social arena, as one recently widowed farmer explained:

You just sit there with negative thoughts. Sitting [at] home feeling sorry for yourself all the time and pondering on sad things. You can get over it, but it is almost necessary to get out and meet people. When my wife died, [in] autumn 2013, I saw no bright side of life. I hardly knew which foot I was going to stand on. I knew nearly nothing. I couldn't even wash my own clothes. But when I came here [to the volunteer centre, last year], I came to life at once.

For this man, coming to life was related to socializing and meeting others at the volunteer centre, which motivated him to get on in life. Another contextual factor that the participants addressed was changes in society. Centralization and changed relationships between neighbours constituted an equally important explanation for the volunteers' appreciation of their voluntary work. One of the women explained why she valued the volunteer centre as meeting place as follows:

The most important for me is the compassion [...] We [the volunteers] knew each other before, but usually we only said "Hello" when we occasionally met at the grocery store. Now we meet almost every day [...] The days when neighbours dropping in at each other ['s house] for coffee at noon are gone. You are sitting by yourself. But this is a meeting place.

The volunteer centre became a new meeting place in the daytime, where they could find alternatives to the neighbourliness they had experienced earlier. They did not need an invitation or a distinct purpose to go to the volunteer centre, and they could be there either as a volunteer or as a guest. Thus, the volunteer centre fulfilled the older adults' need for a place in which to be active and social in everyday life, thereby nurturing their feelings that they were participating in society despite their ageing.

\subsection{Belonging to a Fellowship of Co-Volunteers}

An additional main benefit of volunteering in older age was socialization with other volunteers. Fellowship with other volunteers extended the volunteers' social network and gave them a feeling of having social support. Working with other older adult volunteers was seen as expanding their social network at a time in life when relationships more often end than start. Moreover, acquaintances may become friends, as one of the women explained: 
We don't get to know each other before we work together as volunteers. That's something else [...] It's completely different. You can say other things now, it's true. We learn to know each other in a completely different way. We who sit here around this table have known each other for forty to fifty years, but not like this. It's totally different [...] People are a lot nicer than I believed [...] Many are different from what you thought. There is something else here. I cannot explain it [...] We knew about each other [...] Before we were at work and then we hadn't time to talk with each other. Mostly we just said "Hello" and we were engaged in clubs, associations, and things like that [...] But now we can sit down together [in a] twosome and talk with each other "under the skin", more than we did before, confidentially.

Working together as volunteers provided an opportunity for the older villagers to get to know their fellow volunteers in new ways. This marked a shift from knowing about each other to know each other. Volunteering gave them opportunities to see each other from new angles through cooperation in common tasks. As older adult volunteers, they also found time to talk together in more profound ways than they had experienced earlier. As revealed in the quotation above, the women knew her fellow volunteers from the inside, "under the skin", and not from the outside, rushing by. Volunteering enabled the older people to expand their social networks to include co-volunteers, and by working together on regular basis they had developed valuable strong friendships.

Through companionship and fellowship, the volunteers experienced the social support of co-volunteers. They felt they could ask their co-volunteers for help if needed and they benefitted from their emotional support in difficult times. Such support was expressed as, for example: "I don't need any psychologists, no. Here, we are so many psychologists that we cope." The volunteers experienced the care of the other volunteers when they faced tough times and when family members had serious illnesses. One of the women described this support as follows:

I can talk for myself. It was a period in my life that only contained disease and with death as the exit. In the time at the hospital, and running between treatments at different hospitals, all the time there were regards from everyone. One was calling [...] and [saying] "I should greet you from the others." They called in turn, and it was very nice. Coming home, it was the same. You felt like having a big flock of what I almost would call siblings.

The volunteers experienced practical and emotional support in the fellowship of their co-volunteers, as having someone who stood up if they needed it and to whom who could relate their situation. They experienced that they could ask their co-volunteers for help if necessary, but equally importantly they knew that someone was concerned about their well-being in difficult times and that they would be missed if they did not show up for work.

\subsection{Growth and Adaption to Old Age}

In addition to participation in society and the values of belonging to a fellow- 
ship, the volunteers' work at the volunteer centre became a way for them to adapt positively to old age. In this respect, there were three subthemes: feeling productive and empowered by new challenges and cooperation, forgetting about the challenges of ageing, and volunteering as "door-opener" to active ageing.

The volunteers rediscovered their productive capacity through common efforts, expressed as feeling productive and empowered by new challenges and cooperation. One of the elderly farmers explained:

You should have been here on Mondays when we peel the potatoes. We are sitting in a big circle and there are a lot of topics discussed and a lot of problems solved. It's amusing working together [...] It's clever working together [...] My neighbour says that the power of the common people uniting shouldn't be underestimated. It's fun to solve a task together. As last week, cutting vegetables for the stew, it was like a production line through the kitchen here. It was done in no time. And when you see how much we can achieve when we work together like this [...].

Cooperation was not only a necessity to get the job done but also source of companionship and gave the volunteers a feeling of empowerment. They experienced that despite their age they had the power to create a popular meeting place that brought generations together through serving traditional Norwegian home cooking. They had pride in their work and they felt a sense of ownership of the volunteer centre and the services provided. Through volunteering, they became providers and not merely consumers.

One example of enabling activities is, as mentioned in the quotation above, the "potato-peeling-circle". The participants described the resistance they had felt when someone had tried to mechanize the task, as the oldest women explained:

There was someone who tried to introduce a machine [for] peeling potatoes, but no one wanted it because then the social [side] would have disappeared. There are many volunteers who had said, when they no longer cope with working in the kitchen, they will come to peel the potatoes.

Outsiders might have wondered why they had refused to mechanize the rather laborious and repetitive work, but for this woman it was rather obvious: "Because we shall have the togetherness, we who peels the potatoes. You can't talk with a machine. That's nothing." She could not relate to a machine, and the idea of mechanization threatened her task at the centre. Another woman volunteer added: "This [the volunteer centre] is the only workplace without an age limit. Here, they work until the life stops itself. You could call it natural retirement. Enjoyment has a lot to say. There is little absenteeism." The oldest woman supported her statement as follows: "No. I am healthy on Mondays [the day I volunteer to peel potatoes], even if I am ill the night before and the day after."

Thus, the volunteer centre was a place where the older people could participate and take joy in volunteering and feeling productive, despite their ageing 
and disabilities. There were many different tasks to take care of and therefore "all hands were needed".

With regard to the subtheme forgetting about the challenges of ageing, the volunteer centre became a place to be healthy and to forget about health problems. The volunteers thought of their volunteering as health promoting:

You are not concerned with illness being here [...] Instead, we are talking about how grateful we are for being healthy. If you, one morning, should wake up wondering about what you should do today, it would not fit for me. Knowing I have a job to go to, even if it is not every day [...] It keeps me healthy. If everything suddenly should stop, and no one needed me any more [...] It would have been difficult. This [volunteering] is like a prescription for health. Aging slows down when you are having something to do.

Volunteering gave them a feeling of still being valued as important. To be engaged as volunteers made them feel healthy and slowed down their ageing process.

Volunteering provided social impulses and experiences that the volunteers could take home, which they felt had a positive effect on their health. The following quotes are from a discussion between five members of the men's focus group, when reflecting on the question: What are you getting back from volunteering?

A: We are reloading.

B: Socially, you mean?

C: I think so. It keeps the spirits up. You see, when you on your own, sitting by the kitchen table and staring at the walls [...] But here, you have something looking forward to [...] When you come home you are thinking of the ones you met, the things you discussed, you know [...] bits of everything. It affects the health [...] it really does [...].

D: But sometimes coming home I'm so tired that I'm falling at sleep at once. However, the next morning I'm as fresh and fast, like I haven't been at work.

[short sidetrack in the discussion related to whether they really could become healthier in their age]

A: But you get motivated to do things at home. You know, by having a change from daily life.

B: Absolutely!

E: You get your batteries charged.

The participants considered volunteering as a means to "socially reload" and a source of health due to receiving social impulses and forgetting about the challenges of ageing.

The third and last subtheme concerned volunteering as a "door-opener" to active ageing in general, beyond the voluntary work at the centre. One of the men who had volunteered from the start shared his observations on some of his new 
co-volunteers:

It does something with people. I've seen several examples of that. People you never met before, they weren't outside. Now, after they started here and been here some years [...] they participate in other things as well, such as coming along on bus tours. It's actually like they got a new life. As they have discovered coming out, socializing. That's important. It becomes a problem when you're on your own, staring at the walls and not going outside. It becomes harder. We're not made to stare at the walls. Then you start to ruminate about the past [...].

There was an agreement among the other members of the group about his observation that volunteering helped people to adapt to old age. As a result of volunteering, their social lives had improved and the volunteer centre functioned as a "door-opener" to other social arenas, initially when they were volunteers in their daily work, then through their appreciation of the companionship and activities of the voluntary staff and of the centre as a meeting place, and finally by joining in more traditional activities for older adults, such as the pensioners association.

Taking on new challenges in older life, such as volunteering, had brought new possibilities for the volunteers-possibilities to take advantage of the their stage in life, discover new sides of themselves and each other, and to be viewed in new ways by the community. They could use and develop both their own resources and the resources represented by the other volunteers for their personal growth in adapting to old age.

\section{Discussion}

The aim of our study was to explore the experience of personal outcomes of volunteering as expressed by older adults in a Norwegian volunteer centre. The older adult volunteers described three interconnected outcomes of their volunteering. First, volunteering gave them the opportunity to participate in society, have meaningful content in their everyday life, and to contribute to society, and gave them access to a social arena in times of role transition. Second, volunteering enabled them to access the fellowship of their co-volunteers who were in the same life situation as themselves. This fellowship expanded their social networks and gave them a feeling of social support. Third, and finally, growth and adaption gave the volunteers a feeling of empowerment, helping them to forget about the challenges of ageing, and were a "door-opener" to active ageing.

Earlier studies have revealed that the meaning of voluntary work changes over the life course [29] and some studies have shown that the social benefits are more favourable for older adults than volunteers in other age groups [17] [25]. Our finding that social elements are key benefits of volunteering is in line with other studies of volunteering in the older adult population [13] [21].

In the analysis, a prominent finding was that the older adults' descriptions of their self-perceived benefits from volunteering were intertwined with their social context, namely their stage of life, society's development, changes their local community, and the organization of their everyday work as volunteers at the 
volunteer centre. This supports the importance of not ignoring the local social and cultural information of older adults' engagement in volunteer work [41].

The study participants attributed a high value to their contact with other older adult volunteers in their work. This may have been reinforced at the studied volunteer centre by the lack of other social arenas in the village and the fact that many of the volunteers knew of or knew each other in advance, which is hard to avoid in a small rural community. However, there was no indication that the volunteers had needs that differ from older adults residing elsewhere. Rather, the rural context may have contributed to clarify these self-perceived benefits and their generation with regard to socialization.

The organization of the voluntary work made it possible for the volunteers to adapt their efforts and for them to contribute their own resources, despite their age or disabilities. Their teamwork was, as they stated, "the power of the common people uniting". In being able to combine their efforts through cooperation, they had the power to be productive at an age when they were no longer counted as part of the workforce.

Few studies have focused on the importance of organizational support in promoting the benefits of volunteering among older adults [42], and organizational support has been described as a neglected factor in research related to voluntary work in general [43]. Although their study was not of older adults, Hildago and Moreno [43] found that the characteristics of the tasks and jobs performed by volunteers were a main predictor of worker satisfaction and motivation. Our study shows that volunteers' experiences of working in self-organized teams together with other older adults supplying on-hand services for the local community in a popular meeting place in the village were important contexts for their self-perceived benefits. In this respect, our study supports the findings by Fraser et al. [21] of joint activities valued by citizens as drivers behind by retiree volunteers' feelings of empowerment and belonging.

Having the opportunity to make use of and to develop their compassion through new challenges and collaboration was valued by the volunteers in our study, and this finding corresponds with findings from earlier studies. For example, Bronstein and Mason [25] found that friendship and opportunities to gain knowledge and skills had equal value, and Piercy, Cheek and Teemant [44] found that increased connections with others volunteers were empowering in terms of support and encouragement along with feelings of intimacy and personal satisfaction. These feelings were not only generated by the volunteers supporting themselves but also from gaining a new depth of understanding and acceptance of others. Adding to this literature, stimulation of adaptive abilities by the challenges arising from and resolved in companionship with other older adult volunteers in a supportive environment seems favourable to personal growth. Ryff [45] identified personal growth as a core dimension for well-being and successful ageing.

Our findings indicate that organizers of voluntary work should not neglect older adult volunteers and their needs regarding personal growth and encour- 
agement of their personal and interpersonal resources.

One overall finding relating to the three main themes presented in the analysis was that the older adults considered their volunteering late in life as health promoting, both in terms of forgetting problems and by strengthen their health. When trying to model the connection between the volunteers' experience of volunteering as health promoting and the context of their volunteer engagement, we turned to Raeburn and Rootman's model for people-centred health promotion [46]. Raeburn and Rootman highlight the need to start with people's experiences, but also that people's experiences of health are grounded in ordinary, everyday contexts. They describe health promotion as dealing with real life in the community and based on people doing things together.

Using the categories being, belonging, and becoming, Raeburn and Rootman [46] conceptualized quality of life and determinants for well-being by the degree to which people enjoy important possibilities in their lives. In our study, being was related to participation in society though the volunteers' possibilities to use their resources and have their minds preoccupied with something other than loneliness, loss, and illness. Belonging, in the sense of having fellowship, strengthened the volunteers' social networks and gave them access to social support. Additionally, they felt that the opportunity for personal growth and adaption to old age kept them active and healthy. The latter category of becoming is somewhat similar to Raeburn and Rootman's becoming, for our study participants, it meant becoming an active elderly citizen.

The findings from our study support Hank and Erlinghagen's claim [47] that volunteering is a prominent example of a productive activity, benefiting both society and the volunteers by giving them access to health promoting factors. Volunteering leads to interactions with other older adults and society, which, as described by Ziegelmann and Knoll [48], can be understood as a distal health behaviour and as a psychosocial pathway to health-related outcomes. Our findings support Söderhamn et al.'s [49] finding that the context of volunteering for older adults is important for the benefits they experience and for their retention related to be part of a social setting, having an influence on the voluntary work, and the possibility to develop. However, there is a need for a better understanding of these dynamics in daily voluntary work and the generation of positive health benefits from the older adult volunteers' perspective.

\section{Conclusions and Implications}

The older adults in our study experienced a number of social, self-perceived benefits as a result of volunteering at the volunteer centre. These self-perceived benefits were described as health promoting through empowerment, as a preoccupation that gave support in difficult times, and as a way to "social reload" that kept them healthy. However, there is a need for further in-depth research on the everyday lives of volunteers in order to identify the generating powers of these benefits. In an aging population, knowledge of maintenance factors can contribute to keep older adults as volunteers for longer, thereby generating benefits both for themselves and society. 
This small-scale qualitative study contributes older adults' detailed descriptions of their self-perceived benefits of volunteering in a case when all were volunteers at the same volunteer centre. Some limitations need to be addressed with regard to the study sample and the findings. The characteristics of the participants were not recorded in accordance with social-selection theories and this may have affected the findings. Additionally, the rural context might have had an impact on their appreciation of their work at the volunteer centre, given the lack of other social arenas for older adults in the village.

Despite the limitations, our findings suggest there is a need to address the practical organization of volunteer activities in order to understand better the dynamics behind adult volunteers' self-perceived benefits of volunteering. Such knowledge is important in order to design arenas for older adult volunteer and to optimize the organization of their voluntary work, thereby stimulating their empowerment and health promoting benefits by taking advantage of the opportunities for social interaction. Nurturing the resources that older adult volunteers represent and empowering these volunteers is of global interest for older adults and the societies in which they live. Studies that aim to identify the generating mechanisms behind retention of older old adult volunteers may yield knowledge that is relevant across cultures and national borders. Our study indicates that matching the characteristics of the local community, the inhabitants' needs, and the older adults' resources is important when establishing arenas for older adults' volunteers.

\section{Acknowledgements}

The authors wish to thank the volunteers who participated in the study as well as the volunteers who attended the volunteers' annual meeting for their review of the findings.

\section{Statement of Ethical Approval}

The participants were provided with written and oral information in advance of the interviews. The project was conducted in accordance with the guidelines provided by the National Committee for Research Ethics in the Social Sciences, Law and the Humanities (NESH) [50]. According to the guidelines of the Norwegian Centre for Research Data (NSD), the study did not require a license under the Personal Data Act [51].

Background information on age span and median age was provided by the manager of the volunteer centre.

\section{Funding}

The study was made possible through funding from the Norwegian Extra Foundation for Health and Rehabilitation (Extra Stiftelsen).

\section{Declaration of Contribution of Authors}

All stages of the research process were carried out by both authors. However, the 
first author, in close cooperation with the co-author regarding the structure and content, wrote the article.

\section{Conflict of Interest}

There is no conflict of interest.

\section{References}

[1] World Health Organization (2015) Ageing and Health. FactSheet No. 404, September 2015. http://www.who.int/mediacentre/factsheets/fs404/en/

[2] Dury, S., De Donder, L., De Witte, N., Buffel, T., Jacquet, W. and Verté, D. (2015) To Volunteer or Not: The Influence of Individual Characteristics, Resources, and Social Factors on the Likelihood of Volunteering by Older Adults. Nonprofit and Voluntary Sector Quarterly, 44, 1107-1128. https://doi.org/10.1177/0899764014556773

[3] Morrow-Howell, N., Lee, Y.S., McCrary, S. and McBride, A. (2014) Volunteering as a Pathway to Productive and Social Engagement among Older Adults. Health Education \& Behavior, 41, 84-90. https://doi.org/10.1177/1090198114540463

[4] UN Volunteers (2001) Volunteering and the United Nations System: Working for a Better World. https://www.unv.org/sites/default/files/A\%20RES\%2056\%2038.pdf

[5] Lorentzen, H. (2010) Det sivile samfunn. In: Frønes, I. and Kjølsrød, L., Eds., Det norske samfunn, 6th Edition, Gyldendal Akademisk, Oslo, 308-326.

[6] Norges frivilligsentraler (2017) Velkommen til Norges Frivilligsentraler. http://norgesfrivilligsentraler.no/

[7] Folkestad, B., Christensen, D.A., Stømsnes, K. and Selle, P. (2015) Frivillig innsats i Noreg 1998-2014. Senter for forskning på sivilsamfunn og frivillig sektor, Bergen and Oslo.

[8] Sivesind, K.H. (2005) Seniorers deltakelse i frivillig arbeid: Betydningen av alder og livssituasjon. Institutt for samfunnsforskning, Oslo.

[9] Godbout, E., Filiatrault, J. and Plante, M. (2012) La participation des aînés à des activités de bénévolat: Une revue systématique. Canadian Journal of Occupational Therapy, 79, 23-32. https://doi.org/10.2182/cjot.2012.79.1.4

[10] Tang, F. and Morrow-Howell, N. (2008) Involvement in Voluntary Organizations: How Older Adults Access Voluntary Roles? Journal of Gerontological Social Work, 51, 210-227. https://doi.org/10.1080/01634370802039494

[11] Narushima, M. (2005) "Payback Time": Community Volunteering among Older Adults as a Transformative Mechanism. Aging \& Society, 25, 567-584. https://doi.org/10.1017/S0144686X05003661

[12] Li, T. and Ferraro, K.F. (2005) Volunteering and Depression in Later Life: Social Benefit or Selection Processes? Journal of Health and Social Behavior, 46, 68-84. https://doi.org/10.1177/002214650504600106

[13] Lum, T.Y. and Lightfoot, E. (2005) The Effects of Volunteering on the Physical and Mental Health of Older People. Research on Aging, 27, 31-55. https://doi.org/10.1177/0164027504271349

[14] Morrow-Howell, N., Hinterlong, J., Rozario, P. and Tang, F. (2003) Effects of Volunteering on the Well-Being of Older Adults. Journal of Gerontology: Social Sciences, 58, S137-S145. https://doi.org/10.1093/geronb/58.3.S137

[15] Musick, M.A., Herzog, A.R. and House, J.S. (1999) Volunteering and Mortality among Older Adults: Findings from a National Sample. Journal of Gerontology: So- 
cial Sciences, 54B, S173-S180. https://doi.org/10.1093/geronb/54B.3.S173

[16] Shmotkin, D., Blumstein, T. and Modan, B. (2003) Beyond Keeping Active: Concomitants of Being a Volunteer in Old-Old Age. Psychology and Aging, 18, 602 607. https://doi.org/10.1037/0882-7974.18.3.602

[17] Connolly, S. and O'Shea, E. (2015) The Perceived Benefits of Participating in Voluntary Activities among Older People: Do They Differ by Volunteer Characteristics? Activities, Adaption \& Ageing, 39, 95-108. https://doi.org/10.1080/01924788.2015.1024075

[18] Bonsdorff, M.B. and Rantanen, T. (2011) Benefits of Formal Voluntary Work among Older People: A Review. Ageing Clinical and Experimental Research, 23, 162-169. https://doi.org/10.1007/BF03337746

[19] Cattan, M., Hogg, E. and Hardill, I. (2011) Improving Quality of Life in Ageing Populations: What Can Volunteering Do? Maturitas, 70, 328-332. https://doi.org/10.1016/j.maturitas.2011.08.010

[20] Morrow-Howell, N. (2010) Volunteering in Later Life: Research Frontiers. Journal of Gerontology: Social Sciences, 65B, 461-469. https://doi.org/10.1093/geronb/gbq024

[21] Fraser, J., Clayton, S., Sickler, J. and Taylor, A. (2009) Belonging at the Zoo: Retired Volunteers Conservation, Activism and Collective Identity. Ageing \& Society, 29, 351-368. https://doi.org/10.1017/S0144686X08007915

[22] McMunn, A., Nazroo, J., Wahrendorf, M., Breeze, E. and Zaninotto, P. (2009) Participation in Social-Productive Activities, Reciprocity and Wellbeing in Later Life: Baseline Results in England. Ageing \& Society, 29, 765-782. https://doi.org/10.1017/S0144686X08008350

[23] Tabassum, F., Mohan, J. and Smith, P. (2016) Association of Volunteering with Mental Well-Being: A Lifecourse Analysis of a National Population-Based Longitudinal Study in the UK. BMJ Open, 6, e011327. https://doi.org/10.1136/bmjopen-2016-011327

[24] Van Willigen, M. (2000) Differential Benefits of Volunteering across the Life Course. Journal of Gerontology. Social Sciences, 55, S308-S318. https://doi.org/10.1093/geronb/55.5.S308

[25] Okun, M.A. and Schultz. A. (2003) Age and Motives for Volunteering: Testing Hypotheses Derived from Socioemotional Selectivity Theory. Psychology and Aging, 18, 231-239. https://doi.org/10.1037/0882-7974.18.2.231

[26] Bronstein, L.R. and Mason, S.E. (2013) A Serial Focus Group Model for Under-Standing Experiences of Older Adult Volunteers and Non-Profit Agency Managers. Groupwork, 23, 67-87.

[27] Greenfield, E.A. and Marks, N.F. (2004) Formal Volunteering as a Protective Factor for Older Adults' Psychological Well-Being. Journal of Gerontology: Social Sciences, 59, S258-S264. https://doi.org/10.1093/geronb/59.5.S258

[28] Borgonovi, F. (2008) Doing Well by Doing Good: The Relation between Formal Volunteering and Self-Reported Health and Happiness. Social Science \& Medicine, 66, 2321-2334.

[29] Wilson, J. (2012) Volunteerism Research: A Review Essay. Nonprofit and Voluntary Sector Quarterly, 41, 176-212. https://doi.org/10.1177/0899764011434558

[30] Denzin, N.K. and Lincoln, Y.S., Eds. (2005) The Discipline and Practice of Qualitative Research. In: Denzin, N.K. and Lincoln, Y.S., Eds., The Sage Handbook of Qualitative Research, 3rd Edition, Sage, London, 1-32.

[31] Steward, D.W. and Shamdasani, P.N. (2015) Focus Groups: Theory and Practice, 
3rd Edition, Sage, London.

[32] Prabhakar, R. (2012) What Do the Public Think of Taxation? Evidence from a Focus Group Study in England. Journal of European Social Policy, 22, 77-89. https://doi.org/10.1177/0958928711425266

[33] Kitzinger, J. (2005) Focus Group Research: Using Group Dynamics to Explore Perceptions, Experiences and Understandings. In: Holloway, I., Ed., Qualitative Research in Health Care, Open University Press, Maidenhead, 56-70.

[34] Creswell, J.W. (1998) Qualitative Inquiry and Research Design: Choosing among Five Traditions. Sage, Thousand Oaks, CA.

[35] Malterud, K. (2012) Fokusgrupper som forskningsmetode for medisin og helsefag. Universitetsforlaget, Oslo.

[36] Morgan, D.L. (2010) Reconsidering the Role of Interaction in Analyzing and Reporting Focus Groups. Qualitative Health Research, 20, 718-722. https://doi.org/10.1177/1049732310364627

[37] Braun, V. and Clarke, V. (2006) Using Thematic Analysis in Psychology. Qualitative Research in Psychology, 3, 77-101. https://doi.org/10.1191/1478088706qp063oa

[38] Elo, S. and Kyngäs, H. (2008) The Qualitative Content Analysis Process. Journal of Advanced Nursing, 62, 107-115. https://doi.org/10.1111/j.1365-2648.2007.04569.x

[39] Miller, W.L. and Crabtree, B.F. (2005) Clinicalresearch. In Denzin, N.K. and Lincoln, Y.S., Eds., The Sage HandbookofQualitative Research, 3rd ed. Thosand Oaks, Sage, CA, 605-639.

[40] Elliot, R., Fisher, C.T. and Rennie, D.L. (1999) Evolving Guidelines for Publication of Qualitative Research Studies in Psychology and Related Fields. British Journal of Clinical Psychology, 38, 215-229.

[41] Lorentzen, B., Wikstrøm, B.-M. and Joranger, P. (2014) Voluntary Work for Public Health-Older Volunteers' Participation in a Norwegian Society: Motivation Factors for Participating-Enriching Life and Positive Health. Open Journal of Nursing, 4, 724-729. https://doi.org/10.4236/ojn.2014.411077

[42] Tang, F., Morrow-Howell, N. and Choi, E. (2010) Why Do Older Adult Volunteers Stop Volunteering? Aging \& Society, 30, 859-878. https://doi.org/10.1017/S0144686X10000140

[43] Hidalgo, C.M. and Moreno, P. (2009) Organizational Socialization of Volunteers: The Effect on Their Intentions to Remain. Journal of Community Psychology, 37, 594-601. ttps://doi.org/10.1002/jcop.20317

[44] Piercy, K.W., Cheek, C. and Teemant, B. (2011) Challenges and Psycosocial Growth for Older Volunteers Giving Intensive Humanitarian Services. The Gerontologist, 55, 550-560. https://doi.org/10.1093/geront/gnr013

[45] Ryff, C.D. (1989) Beyond Ponce de Leon and Life Satisfaction: New Directions in Quest of Successful Ageing. International Journal of Behavioral Development, 12, 33-55. https://doi.org/10.1177/016502548901200102

[46] Raeburn, J. and Rootman, I. (1998) People-Centered Health Promotion. Wiley, Chichester.

[47] Hank, K. and Erlinghagen, M. (2009) Dynamics of Volunteering in Older Europeans. The Gerontologist, 50, 170-178. https://doi.org/10.1093/geront/gnp122

[48] Ziegelmann, J.P. and Knoll, N. (2015) Future Directions in the Study of Health Behavior among Older Adults. Gerontology, 61, 469-476.

[49] Söderhamn, U., Landmark, B., Aasgaard, L., Eide, H. and Söderhamn, O. (2012) Volunteering in Dementia Care-A Norwegian Phenomenological Study. Journal of Multidisciplinary Healthcare, 5, 61-67. https://doi.org/10.2147/JMDH.S28240 
[50] NESH (National Committee for Research Ethics in the Social Sciences, Law and the Humanities) (2006) National Guidelines for Research Ethics in the Social Sciences, Law and the Humanities.

https://www.etikkom.no/globalassets/documents/english-publications/guidelines-fo r-research-ethics-in-the-social-sciences-law-and-the-humanities-2006.pdf

[51] Datatilsynet [The Norwegian Data Protection Authority] (2000) Personal Data Act. https://www.datatilsynet.no/English/Regulations/Personal-Data-Act-/

Submit or recommend next manuscript to SCIRP and we will provide best service for you:

Accepting pre-submission inquiries through Email, Facebook, LinkedIn, Twitter, etc. A wide selection of journals (inclusive of 9 subjects, more than 200 journals)

Providing 24-hour high-quality service

User-friendly online submission system

Fair and swift peer-review system

Efficient typesetting and proofreading procedure

Display of the result of downloads and visits, as well as the number of cited articles Maximum dissemination of your research work

Submit your manuscript at: http://papersubmission.scirp.org/

Or contact jss@scirp.org 